\title{
Cropping Pattern in Flood Prone Areas of Bihar: A Study in Perennially Flood Prone Districts of North Bihar
}

\author{
Priyanka Kumari", KM. Singh, and Nasim Ahmad \\ Department of Agricultural Economics, Dr. Rajendra Prasad Central Agricultural University, \\ Pusa (Samastipur), Bihar, Pin-848125 \\ *Corresponding author
}

\section{A B S T R A C T}

\begin{tabular}{|l|}
\hline Ke y w o r d s \\
$\begin{array}{l}\text { Cropping Pattern, } \\
\text { Food grains, Land, } \\
\text { Limited resources, } \\
\text { Adoption }\end{array}$ \\
\hline Article Info \\
\hline $\begin{array}{l}\text { Accepted: } \\
\text { 22 June } 2020 \\
\text { Available Online: } \\
\text { 10 July } 2020\end{array}$ \\
\hline
\end{tabular}

\section{Introduction}

Agriculture is the prime sector of the state economy. The performance of the agriculture sector influences the growth of economy and it helps in the development and growth of the industrial sector since agriculture sector provides the raw material to the industrial sector. The implications of a sustained growth of agricultural sector are huge for the economy of Bihar. Bihar is the third populous state after Uttar Pradesh and Maharashtra. According to the 2011 census, 88.70 percent of populations live in rural areas where agriculture is the main occupation.
Cropping pattern here has been defined as distribution of acreages expressed in percentages of total cropped area (Ramasubban, 1963). Cropping pattern in different regions determine the output mix. It has significant bearing on widening the geographical inequalities in income distribution. It was therefore, considered worthwhile to measure the changes in cropping patterns over a period of time and between the zones.

The selection of crops is very important, in the agro - climatic conditions of the district under study. 


\section{Materials and Methods}

Bihar, one of the states of the Eastern India, is located between $21^{0} 58^{\prime} 10^{\prime \prime}$ to $27^{0} 31^{\prime} 15^{\prime \prime}$ " north latitude and $83^{\circ} 9^{\prime} 50^{\prime \prime}$ to $88^{\circ} 17^{\prime} 47^{\prime \prime}$ east longitude and covers an area of 1.74 lakh sq $\mathrm{km}$ surrounded by four states and an international boarder. Northern Bihar receives water from the Himalayan rivers and is largely flood prone. The cropping pattern of the project area is studied at four points of time i.e., (TE-1985, TE-1995, TE-2005 and TE-2016) on decadal basis. Cropping pattern for individual year will not give any additional information since there is no evidence of significant change in cropping pattern between consecutive years. The crops selected for the study were rice, wheat, maize and barley, red gram, gram, lentil, pea, Lathyrus (khesari), oilseeds, sugarcane and potato. Other related information are obtained from different issues of Economic Survey of Bihar, Agriculture Statistics at a Glance, Ministry of Agriculture, Govt. of India, Statistical Handbook, Govt. of Bihar and website of Cost of Cultivation.

\section{Results and Discussion}

\section{Cropping pattern in Bihar}

Cropping pattern may be defined as the proportion of area under different crops in a given period of time. The agro-ecological conditions of the alluvial plains have enabled diversification of cropping system in Bihar. Besides cereals, cultivation of pulses, fruits and vegetables are crucial to meet the food and nutritional needs of the population. The diversification of crops also helps the farmers in risk management. Bihar is primarily a cereal economy, with about 80.92 percent of its gross cropped area under cereals. Despite the emphasis on the need to increase acreage on pulses for ensuring nutritional security. Table 1 and fig. 1 presents the trend in cropping pattern in Bihar during the period 1985-86 to 2015-16. The gross cropped area for the state as a whole has recorded 7999.13 thousand hectares in TE-1985 and 7635.72 thousand hectares in TE-2016. While pulses acreage decreased from 11.36 percent to 6.70 percent during TE-1985 to TE-2016. Food grains (cereals and pulses) together accounted for 87.49 percent of the gross cropped area in the state. Around 3.53 percent of GCA was occupied by sugarcane crop, which indicates limited commercialization of agriculture in the state. While area under oilseeds declined to $1.56 \%$ in TE-2016.

\section{Zone-wise cropping pattern in North Bihar}

\section{Cropping pattern of Agro-climatic Zone-I}

The cropping pattern of Agro-climatic zone-I in Bihar is presented in Table 2 and fig. 2. The gross cropped area in the region has registered fluctuating trend. Similar trend was found in case of area under total cereals. Area under pulse crops in zone-I was also showed declining trend and area under total pulses was reduced to just half during period under study i.e., from $8.57 \%$ (263.14 ha) in TE1985 to $3.96 \%$ (118.09 ha) in TE- 2016. Hence, the farmers prefer not to cultivate pulse crops on their farms. Area under oilseeds remained almost stagnant throughout the period of investigation. Potato and sugarcane exhibited tremendous changes in areas.

The area under sugarcane jumped up from $3.07 \%$ in TE-1985 to $8.77 \%$ in TE-2016, indicating commercialization of agriculture in the state. Most of the sugar factories in Bihar are situated in zone-I and due to Government initiative of direct transfer of benefits to the farmers, cultivation of sugarcane has increased in zone-I. The area under potato also doubled in zone-I from $1.62 \%$ to $3.39 \%$ in TE- 1985 and TE- 2016, respectively 
showing shifting of farmers from mere cereals cultivation to vegetables and cash crops farming.

\section{Cropping pattern of Agro-climatic Zone-II}

Cropping pattern in agro-climatic zone-II of the state has been analyzed and presented in Table 3 and Fig. 3. Zone-II is popular for rabi maize production as this preposition was approved by larger proportion of area under maize crop $17.56 \%$ of the gross cropped area. The area of wheat declined from $20.88 \%$ in TE-2005 to $16.42 \%$ in TE-2016. Further, it was also observed that the area under sugarcane crop has increased from $0.07 \%$ in TE-1985 to $0.31 \%$ in TE-2016.

Table.1 Cropping pattern of Bihar (000’ ha)

\begin{tabular}{|c|c|c|c|c|}
\hline Crops & TE-1985 & TE-1995 & TE-2005 & TE-2016 \\
\hline Paddy & $\begin{array}{c}3499.97 \\
(43.75 \%)\end{array}$ & $\begin{array}{c}3065.97 \\
(39.51 \%)\end{array}$ & $\begin{array}{c}3450.31 \\
(44.98 \%)\end{array}$ & $\begin{array}{c}3215.50 \\
(42.11)\end{array}$ \\
\hline Wheat & $\begin{array}{l}1785.22 \\
(22.32)\end{array}$ & $\begin{array}{l}1930.73 \\
(24.88)\end{array}$ & $\begin{array}{c}2023.40 \\
(26.38)\end{array}$ & $\begin{array}{c}2101.43 \\
(27.52)\end{array}$ \\
\hline Maize & $\begin{array}{l}521.88 \\
(6.52)\end{array}$ & $\begin{array}{c}678.75 \\
(8.75)\end{array}$ & $\begin{array}{c}628.10 \\
(8.19)\end{array}$ & $\begin{array}{l}714.60 \\
(9.36)\end{array}$ \\
\hline Barley & $\begin{array}{l}67.65 \\
(0.85)\end{array}$ & $\begin{array}{l}34.80 \\
(0.45)\end{array}$ & $\begin{array}{l}20.08 \\
(0.26)\end{array}$ & $\begin{array}{c}9.55 \\
(0.13)\end{array}$ \\
\hline Total cereals & $\begin{array}{c}6193.04 \\
(77.42)\end{array}$ & $\begin{array}{c}6238.38 \\
(80.40)\end{array}$ & $\begin{array}{c}6455.48 \\
(84.16)\end{array}$ & $\begin{array}{c}6202.28 \\
(81.23)\end{array}$ \\
\hline Red gram & $\begin{array}{l}53.66 \\
(0.67)\end{array}$ & $\begin{array}{l}49.13 \\
(0.63)\end{array}$ & $\begin{array}{l}36.22 \\
(0.47)\end{array}$ & $\begin{array}{l}21.39 \\
(0.28)\end{array}$ \\
\hline Gram & $\begin{array}{l}149.03 \\
(1.86)\end{array}$ & $\begin{array}{l}136.02 \\
(1.75)\end{array}$ & $\begin{array}{l}70.96 \\
(0.93)\end{array}$ & $\begin{array}{l}59.89 \\
(0.78)\end{array}$ \\
\hline Lentil & $\begin{array}{l}163.14 \\
(2.04)\end{array}$ & $\begin{array}{l}172.06 \\
(2.22)\end{array}$ & $\begin{array}{c}176.66 \\
(2.30)\end{array}$ & $\begin{array}{l}151.02 \\
(1.98)\end{array}$ \\
\hline Pea & $\begin{array}{l}30.65 \\
(0.38)\end{array}$ & $\begin{array}{l}25.48 \\
(0.33)\end{array}$ & $\begin{array}{l}29.87 \\
(0.39)\end{array}$ & $\begin{array}{l}17.16 \\
(0.22)\end{array}$ \\
\hline Lathyrus (khesari) & $\begin{array}{l}329.15 \\
(4.11)\end{array}$ & $\begin{array}{l}172.76 \\
(2.23)\end{array}$ & $\begin{array}{c}131.43 \\
(1.71)\end{array}$ & $\begin{array}{l}59.50 \\
(0.78)\end{array}$ \\
\hline Total pulses & $\begin{array}{l}908.55 \\
(11.36)\end{array}$ & $\begin{array}{l}726.45 \\
(9.36)\end{array}$ & $\begin{array}{c}635.04 \\
(8.28)\end{array}$ & $\begin{array}{l}511.45 \\
(6.70)\end{array}$ \\
\hline Total food grains & $\begin{array}{l}7101.59 \\
(88.78)\end{array}$ & $\begin{array}{c}6967.43 \\
(89.79)\end{array}$ & $\begin{array}{c}7100.52 \\
(92.56)\end{array}$ & $\begin{array}{l}6713.7 \\
(87.93)\end{array}$ \\
\hline Oilseeds & $\begin{array}{l}156.81 \\
(1.96)\end{array}$ & $\begin{array}{l}157.59 \\
(2.03)\end{array}$ & $\begin{array}{c}141.96 \\
(1.85)\end{array}$ & $\begin{array}{l}118.87 \\
(1.56)\end{array}$ \\
\hline Sugarcane & $\begin{array}{l}110.00 \\
(1.38)\end{array}$ & $\begin{array}{l}119.11 \\
(1.53)\end{array}$ & $\begin{array}{l}101.70 \\
(1.33)\end{array}$ & $\begin{array}{l}269.52 \\
(3.53)\end{array}$ \\
\hline Potato & $\begin{array}{l}103.10 \\
(1.29)\end{array}$ & $\begin{array}{l}134.57 \\
(1.73)\end{array}$ & $\begin{array}{l}141.70 \\
(1.85)\end{array}$ & $\begin{array}{l}241.90 \\
(3.17)\end{array}$ \\
\hline Gross cropped area & $\begin{array}{c}7999.13 \\
(100.00)\end{array}$ & $\begin{array}{c}7760.01 \\
(100.00)\end{array}$ & $\begin{array}{c}7670.94 \\
(100.00)\end{array}$ & $\begin{array}{r}7635.72 \\
(100.00)\end{array}$ \\
\hline
\end{tabular}

Figure in parentheses indicate percentage value 
Table.2 Cropping pattern of Agro-climatic Zone- I (000`ha)

\begin{tabular}{|l|c|c|c|c|}
\hline \multicolumn{1}{|c|}{ Crops } & TE-1985 & TE-1995 & TE-2005 & TE-2016 \\
\hline Paddy & 1435.72 & 1286.78 & 1322.62 & 1237.85 \\
& $(46.77)$ & $(42.68)$ & $(45.12)$ & $(41.47)$ \\
\hline Wheat & 717.04 & 812.79 & 876.98 & 933.74 \\
& $(23.36)$ & $(26.96)$ & $(29.92)$ & $(31.28)$ \\
\hline Maize & 352.58 & 294.17 & 283.07 & 301.57 \\
& $(11.49)$ & $(9.76)$ & $(9.66)$ & $(10.10)$ \\
\hline Barley & 25.36 & 6.62 & 4.09 & 0.48 \\
& $(0.83)$ & $(0.22)$ & $(0.14)$ & $(0.02)$ \\
\hline Total cereals & 2558.04 & 2480.16 & 2508.16 & 2417.93 \\
\hline Red gram & $(83.34)$ & $(82.25)$ & $(85.56)$ & $(81.00)$ \\
\hline Gram & 32.53 & 26.49 & 21.42 & 7.88 \\
& $(1.06)$ & $(0.88)$ & $(0.73)$ & $(0.26)$ \\
\hline Lentil & 18.68 & 10.18 & 3.00 & 0.60 \\
& $(0.61)$ & $(0.34)$ & $(0.10)$ & $(0.02)$ \\
\hline Pea & 34.96 & 34.47 & 43.09 & 35.31 \\
& $(1.14)$ & $(1.14)$ & $(1.47)$ & $(1.18)$ \\
\hline Lathyrus (khesari) & 8.05 & 8.05 & 7.67 & 4.24 \\
& $(0.26)$ & $(0.27)$ & $(0.26)$ & $(0.14)$ \\
\hline Total pulses & 40.23 & 19.20 & 22.63 & 3.63 \\
& $(1.31)$ & $(0.64)$ & $(0.77)$ & $(0.12)$ \\
\hline Total food grains & 263.14 & 234.19 & 186.82 & 118.09 \\
\hline Oilseeds & $(8.57)$ & $(7.77)$ & $(6.37)$ & $(3.96)$ \\
\hline Sugarcane & 2821.17 & 2714.36 & 2694.98 & 2536.02 \\
\hline Potato & $(91.91)$ & $(90.02)$ & $(91.94)$ & $(84.95)$ \\
\hline & 47.32 & 63.35 & 56.60 & 51.185 \\
& $(1.54)$ & $(2.10)$ & $(1.93)$ & $(1.71)$ \\
\hline & 94.11 & 105.00 & 95.25 & 261.84 \\
& $(3.07)$ & $(3.48)$ & $(3.25)$ & $(8.77)$ \\
\hline & 49.84 & 68.56 & 69.23 & 101.13 \\
\hline & $(1.62)$ & $(2.27)$ & $(2.36)$ & $(3.39)$ \\
\hline & 3069.50 & 3015.23 & 2931.32 & 2985.18 \\
& $(100.00 \%)$ & $(100.00 \%)$ & $(100.00 \%)$ & $(100.00)$ \\
\hline
\end{tabular}

Figure in parentheses indicate percentage value 
Table.3 Cropping pattern of Agro-climatic Zone- II (000'ha)

\begin{tabular}{|l|c|c|c|c|}
\hline \multicolumn{1}{|c|}{ Crops } & TE-1985 & TE-1995 & TE-2005 & TE-2016 \\
\hline Paddy & 668.54 & 686.99 & 756.90 & 676.02 \\
& $(43.84)$ & $(43.27)$ & $(44.98)$ & $(41.44)$ \\
\hline Wheat & 239.16 & 297.74 & 351.39 & 267.88 \\
& $(15.68)$ & $(18.75)$ & $(20.88)$ & $(16.42)$ \\
\hline Maize & 46.28 & 224.81 & 222.11 & 286.53 \\
& $(3.04)$ & $(14.16)$ & $(13.20)$ & $(17.56)$ \\
\hline Barley & 5.85 & 1.22 & 0.36 & 0.14 \\
& $(0.38)$ & $(0.08)$ & $(0.02)$ & $(0.01)$ \\
\hline Total cereals & 1017.44 & 1237.76 & 1365.75 & 1243.85 \\
& $(66.72)$ & $(77.96)$ & $(81.16)$ & $(76.25)$ \\
\hline Red gram & 2.15 & 2.42 & 2.05 & 0.44 \\
& $(0.14)$ & $(0.15)$ & $(0.12)$ & $(0.03)$ \\
\hline Gram & 6.40 & 6.17 & 5.84 & 0.93 \\
& $(0.42)$ & $(0.39)$ & $(0.35)$ & $(0.06)$ \\
\hline Lentil & 12.94 & 16.73 & 13.08 & 7.52 \\
& $(0.85)$ & $(1.05)$ & $(0.78)$ & $(0.46)$ \\
\hline Pea & 4.08 & 4.69 & 5.20 & 3.18 \\
& $(0.27)$ & $(0.30)$ & $(0.31)$ & $(0.20)$ \\
\hline Lathyrus (khesari) & 41.04 & 21.37 & 16.15 & 4.71 \\
& $(2.69)$ & $(1.35)$ & $(0.96)$ & $(0.29)$ \\
\hline Total pulses & 71.75 & 59.73 & 122.42 & 109.94 \\
& $(4.71)$ & $(3.76)$ & $(7.28)$ & $(6.74)$ \\
\hline Total food grains & 1089.19 & 1297.49 & 1488.17 & 1353.79 \\
& $(71.43)$ & $(81.72)$ & $(88.44)$ & $(82.99)$ \\
\hline Oilseeds & 38.64 & 34.68 & 31.35 & 28.878 \\
\hline Sugarcane & $(2.53)$ & $(2.18)$ & $(1.86)$ & $(1.77)$ \\
\hline Potato & 1.01 & 1.56 & 0.55 & 5.05 \\
& $(0.07)$ & $(0.10)$ & $(0.03)$ & $(0.31)$ \\
\hline & 17.44 & 28.64 & 35.34 & 38.61 \\
\hline & $(1.14)$ & $(1.80)$ & $(2.10)$ & $(2.37)$ \\
\hline & 1524.87 & 1587.66 & 1682.70 & 1631.28 \\
& $(100.00)$ & $(100.00)$ & $(100.00)$ & $(100.00)$ \\
\hline
\end{tabular}

Figure in parentheses indicate percentage value 
Fig.1 Cropping pattern of Bihar

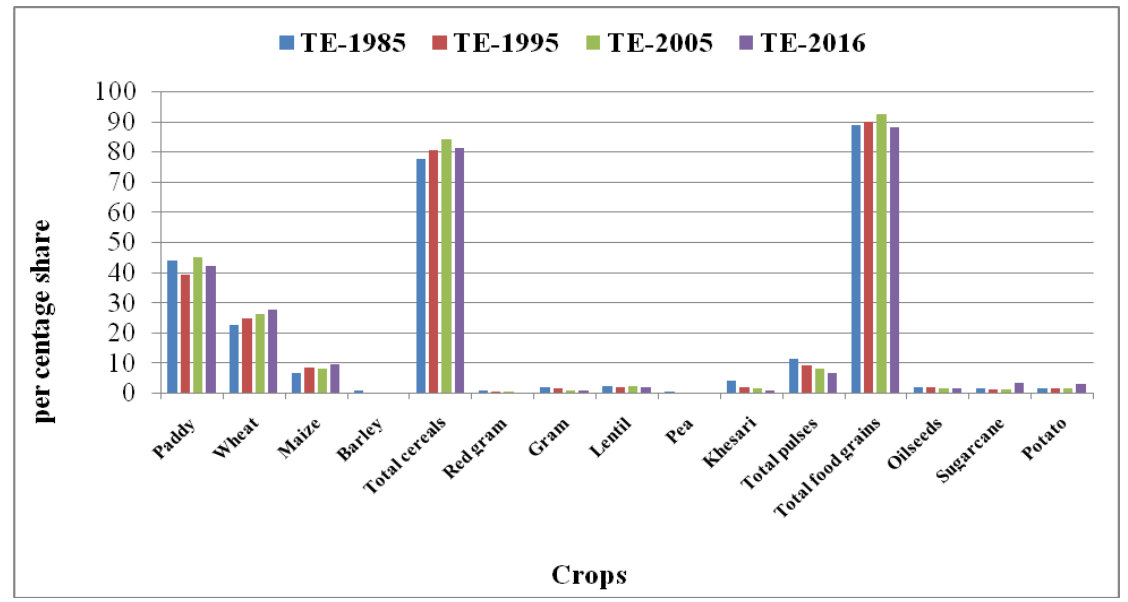

Fig.2 Cropping pattern of Agro-climatic zone-I

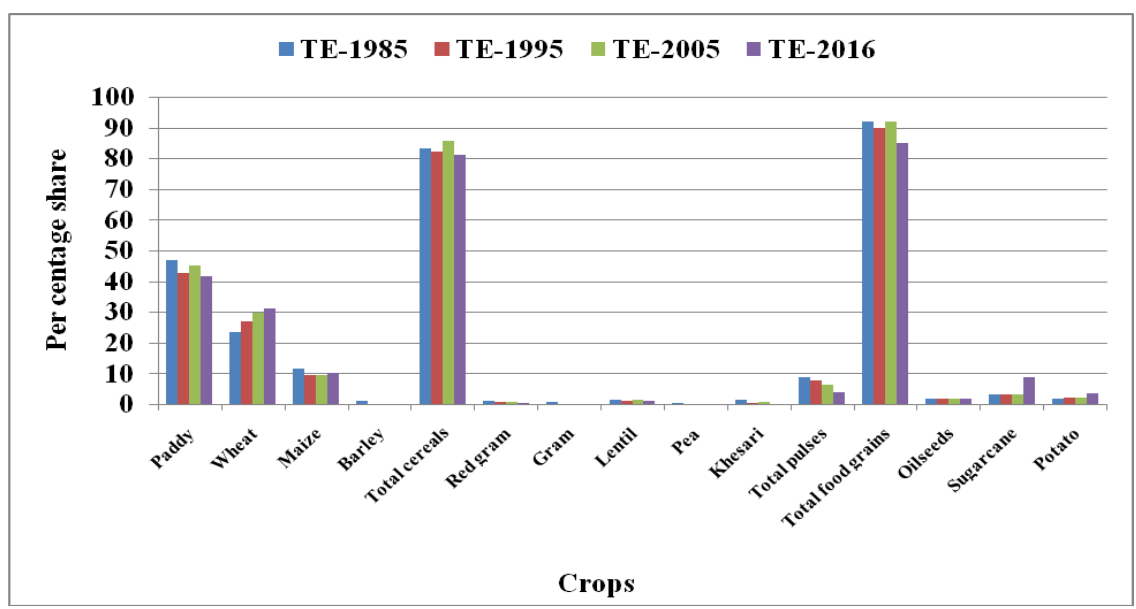

Fig.3 Cropping pattern of Agro-climatic zone-II

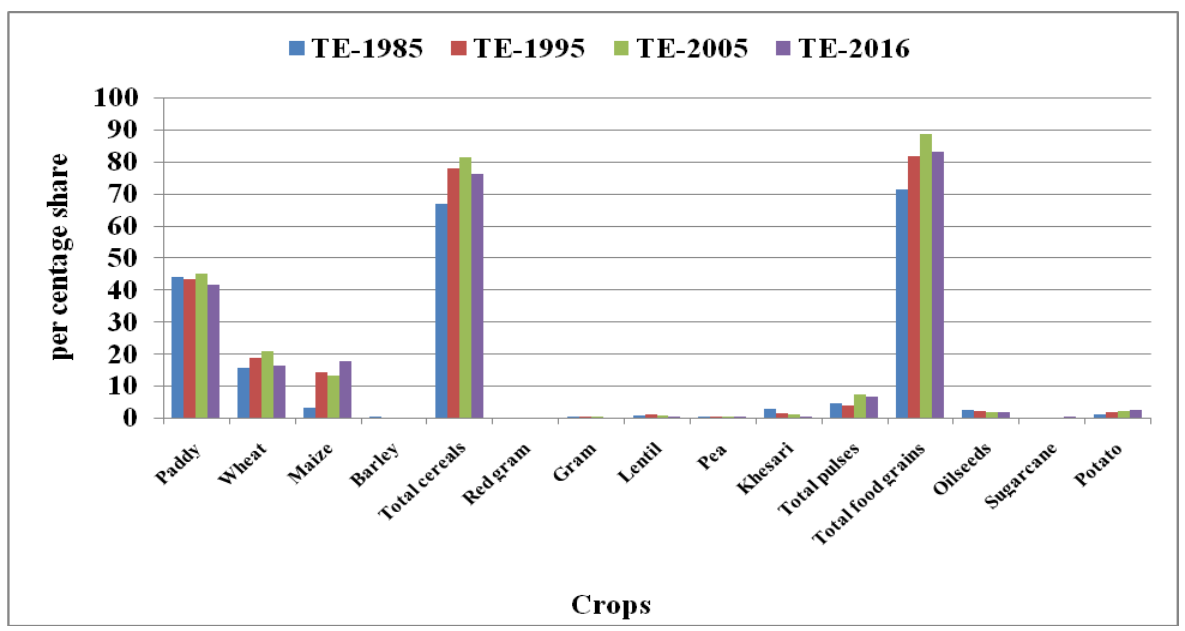


A recent phenomenon observed was that cultivators of this zone considered sugarcane cultivation as more profitable than rabi maize crop because of their perception that sugarcane cultivation requires comparatively less labour as compared to rabi maize as well as sugar factory of the zone is also ensuring direct payment into their account.

Hence, the cultivators of the zone are tempting towards sugarcane cultivation. Percentage area under potato has doubled from TE-1985 to TE-2016.

In conclusion, the considering is the fact that Bihar has achieved self-sufficiency in food grain production, specific schemes for cultivation of pulses and oilseeds in paddy fallows areas have been undertaken in the state under the scheme of 'Targeting Rice Fallow Areas (TRFA) in Eastern India'. On the other hand, the area of sugarcane and potato in the cropping pattern has gone up throughout the study period.

This may probably be on account of diversification of cropping pattern towards vegetables and cash crops in the state. In zone-I, the fluctuating trend in gross cropped area may probably be due to flood situation.

Pulses are generally grown under rain fed condition in the state, they are disease prone and due to sweetness of pods, are often destroyed by stray and wild animal like cattle, nilgai and wild pigs.

In zone II area of wheat declined, which pinpointed the fact that area of wheat was replaced by rabi maize crop during the period 2005-16 and area of potato has doubled which indicate farmer's inclination towards vegetable crops as they considered it comparatively remunerative.

\section{References}

Kumar, A. and Maulick, B. G. (2016), "Agriculture in Bihar: The latent sector of development, International Journal of Humanities and Social Science Invention, 5(2): 9-20.

Gogoi, M. (2016), "Cropping pattern in Sivasagar district, Assam, India: A case study", International Journal of Innovative Research and Development, 5(10): 278-286.

Lalitha, A. (1980), "Cropping Pattern in Andhra Pradesh 1957 to 1977", unpublished thesis of M. Phil, Osmania University, Hyderabad.

Mandal, Raju and Bezbaruah, M. P. (2013), "Diversification of cropping pattern: Its determinants and role in flood affected agriculture of Assam palins", Indian Journal of Agricultural Economics, 68(2): 169-181.

Mondal, H. Mohammad. (2011), "Causes of yield gaps and strategies for minimizing the gaps in different crops of Bangladesh", Bangladesh Journal Agricultural Research, 36(3): 469-476.

Ningaraju and Das, S A (2017), “ Cropping Pattern and Crop Ranking of Mysore District", International Journal of Research - Granthaalahay, 5(4): 334338.

Ram, S. (1999), “Cropping Pattern Diversification in Orissa", Agricultural Situation in India, 56(1): 15-18.

Ramasubban, T.A. (1963), "Some statistical measures to determine changes in cropping pattern", Agricultural situation in India, 17(11): 1153.

Sangral, C. (2015), "Changes in cropping pattern and crop diversification in Jammu and Kashmir", IOSR- Journal of Humanities and Social Science, 20(4), ver. II: 7-9. 
How to cite this article:

Priyanka Kumari, KM. Singh, and Nasim Ahmad. 2020. Cropping Pattern in Flood Prone Areas of Bihar: A Study in Perennially Flood Prone Districts of North Bihar. Int.J.Curr.Microbiol.App.Sci. 9(07): 3476-3483. doi: https://doi.org/10.20546/ijcmas.2020.907.406 